Research article

\title{
Therapeutic effect of the potent IL-12/IL-23 inhibitor STA-5326 on experimental autoimmune uveoretinitis
}

\author{
Hiroshi Keino ${ }^{1}$, Takayo Watanabe ${ }^{1}$, Yasuhiko Sato ${ }^{2}$, Mamoru Niikura ${ }^{3}$, Yumiko Wada ${ }^{4}$ and \\ Annabelle A Okada1
}

\author{
1Department of Ophthalmology, Kyorin University School of Medicine, 6-20-2 Shinkawa, Mitaka, Tokyo, 181-8611 Japan \\ ${ }^{2}$ Division of Radioisotope Research, Kyorin University School of Medicine, 6-20-2 Shinkawa, Mitaka, Tokyo, 181-8611 Japan \\ ${ }^{3}$ Laboratory of Animals, Kyorin University School of Medicine, 6-20-2 Shinkawa, Mitaka, Tokyo 181-8611 Japan \\ ${ }^{4}$ Synta Pharmaceuticals Corporation, 45 Hartwell Ave. Lexington, MA 02421, USA \\ Corresponding author: Hiroshi Keino, keino@eye-center.org
}

Received: 8 Aug 2008 Revisions requested: 4 Sep 2008 Revisions received: 17 Sep 2008 Accepted: 13 Oct 2008 Published: 13 Oct 2008

Arthritis Research \& Therapy 2008, 10:R122 (doi:10.1186/ar2530)

This article is online at: http://arthritis-research.com/content/10/5/R122

(c) 2008 Keino et al.; licensee BioMed Central Ltd.

This is an open access article distributed under the terms of the Creative Commons Attribution License (http://creativecommons.org/licenses/by/2.0), which permits unrestricted use, distribution, and reproduction in any medium, provided the original work is properly cited.

\begin{abstract}
Introduction The purpose of this study was to determine if oral administration of the interleukin (IL) 12/IL-23 inhibitor, STA5326, is effective in experimental autoimmune uveoretinitis (EAU).

Methods C57BL/6J mice were immunised with human interphotoreceptor retinoid binding protein peptide (IRBP $\left.{ }_{1-20}\right)$. STA-5326 at a dose of either $5 \mathrm{mg} / \mathrm{kg}$ or $20 \mathrm{mg} / \mathrm{kg}$, or vehicle alone, was orally administered once a day for six days a week from day 0 to day 14 . Fundus examination was performed on day 14 and day 18 after immunisation. Mice were euthanased on day 18 and the eyes were enucleated for histopathological examination. In vivo-primed draining lymph node cells were stimulated with IRBP ${ }_{1-20}$ and culture supernatant was harvested for assay of interferon (IFN)- $\gamma$ and IL-17 by ELISA. Intracellular expression of IFN- $\gamma$ and IL-17 in $\mathrm{CD}^{+}{ }^{+} \mathrm{T}$ cells of cultured draining lymph node cells was assessed by flow cytometry. The level of IL-12 p40 in serum was examined in STA-5326-treated or vehicle-treated mice receiving immunisation.
\end{abstract}

Results The level of IL-12 p40 in serum was decreased in mice treated with STA-5326. Oral administration of either $5 \mathrm{mg} / \mathrm{kg}$ or $20 \mathrm{mg} / \mathrm{kg}$ STA-5326 reduced the severity of EAU on day 14 and 18. In addition, mice treated with $20 \mathrm{mg} / \mathrm{kg}$ STA-5326 showed significantly decreased severity of EAU by histopathological analysis. Although IFN- $\gamma$ production of draining lymph node cells was increased in STA-5326-treated mice by ELISA analysis, the proportion of IFN- $\gamma$-producing cells was not significantly altered. However, IL-17 production and the proportion of IL-17producing cells were significantly reduced in STA-5326-treated mice. Furthermore, oral administration of STA-5326 during the effector phase reduced the severity of EAU.

Conclusions These results indicate that oral administration of the IL-12/IL-23 inhibitor STA-5326 is effective in suppressing inflammation in the EAU model, and reduces the expansion of IL17-producing cells. STA-5326 may represent a new therapeutic modality for human refractory uveitis.

\section{Introduction}

Interleukin (IL) 23 is a heterodimeric cytokine, sharing a p40 subunit with the Th1 cytokine IL-12, but differing from IL-12 in its unique $\mathrm{p} 19$ subunit $[1,2]$. IL-23 is required for the generation of effector memory $\mathrm{T}$ cells and IL-17-producing $\mathrm{T}$ cells (Th17), which in turn play critical roles in inflammatory responses $[3,4]$. Thus, IL-12/IL-23 has become an attractive clinical target in a number of studies. Investigation into regula- tion of the p40 and IL-23 specific p19 subunits has demonstrated a critical role of IL-12/IL-23 in the pathogenesis of autoimmune disease [5-9]. Recent studies have demonstrated that monoclonal antibodies to the IL-12/IL-23 p40 subunit are effective in human clinical trials for Crohn's disease and psoriasis [10-12].

CFA: complete Freund's adjuvant; EAU: experimental autoimmune uveoretinitis; ELISA: enzyme linked immunosorbent assay; RPMI: Roswell Park Memorial Institute; HEPES: 4-(2-hydroxyethyl)-1-piperazineethanesulfonic acid; PMA: Phorbol 12-Myristate 13 Acetate; FCS: fetal calf serum; IBD: inflammatory bowel disease; IFN: interferon; IL: interleukin; IRBP: interphotoreceptor retinoid binding protein; NF: nuclear factor; SD: standard deviation; Th: T helper; TNF: tumour necrosis factor. 
Experimental autoimmune uveoretinitis (EAU) is an animal model that shares many clinical and histological features with human uveitic disorders such as Behcet's disease [13-15]. Therefore, much information is gained by using the model to analyse the immunopharmacology of various immunosuppressive agents in uveitis. EAU is induced by immunization with a retinal antigen (S-antigen or interphotoreceptor-retinoid binding protein (IRBP)) or by adoptive transfer of retinal antigenspecific CD4+ T cells [16-18]. Recent studies have demonstrated that a Th1/Th17 response to the retinal antigen is dominant in EAU in mice [19-24]. Although previous reports have stated that IL-12 is required for the induction of EAU $[25,26]$, new research has clearly indicated that it is IL-23, rather than $\mathrm{IL}-12$, that is necessary for EAU induction [24].

The nuclear factor (NF) $\kappa \mathrm{B}$ is a popular target for effective blockade of activation of the promoter for genes encoding proinflammatory cytokines in cells involved in innate and adaptive immunity. The NF- $\kappa B$ family includes the p65, RelB, c-Rel, p50 and p52 proteins. Although p50/p65 is the most common form of NF- $\mathrm{KB}$ to activate the promoters of many genes, including those for tumour necrosis factor (TNF)- $\alpha$ and IL-6, the c-Rel-containing form is essential for activation of the p40 gene in macrophages [27]. Furthermore, a recent study of the p19 gene promoter showed that c-Rel binds to the $\kappa B$ sites on this promoter and controls p19 gene expression in dendritic cells [28]. Thus, c-Rel is a specific transcriptional regulator of both IL-12 and IL-23.

STA-5326 is a small molecule developed from a novel triazine derivative identified by high-throughout IL-12 inhibitor screening [29]. STA-5326 inhibits the expression of genes encoding the p40 subunit present in both IL-12 and IL-23 by selective inhibition of c-Rel translocation [29]. The protein c-Rel, a member of the Rel/NF- $\kappa B$ family of transcription factors, requires transport from the cytoplasm to the nucleus for activity. STA5326 blocks the nuclear localization of c-Rel without inhibiting the nuclear import of other Rel/NF- $\kappa B$ family members. Oral administration of STA-5326 led to suppression of inflammation by histopathological analysis in a model of inflammatory bowel disease (IBD) [29]. In the current study, we examined if oral administration of the potent IL-12/IL-23 inhibitor, STA5326, would be effective in EAU.

\section{Materials and methods Animals}

Six- to eight-week-old female C57BL/6J mice were purchased from Japan CLEA (Shizuoka, Japan). All mice were treated in accordance with the ARVO Statement for the Use of Animals in Ophthalmic and Vision Research and institutional guidelines regarding animal experimentation.

\section{Induction and scoring of EAU}

Mice were immunized subcutaneously in the neck region with $200 \mu \mathrm{g}$ of IRBP $_{1-20}$ emulsified in $0.2 \mathrm{ml}$ of complete Freund's adjuvant (CFA) (Difco, Detroit, MI) containing $1 \mathrm{mg}$ of the Mycobacterium tuberculosis strain H37Ra (Difco, Detroit, MI). They were also given 100 ng of pertussis toxin (Sigma, St. Louis, MO) intraperitoneally as additional adjuvant [30]. Funduscopic examination was performed on days 14,15 and 18 after immunization, and clinical findings were graded from 0 to 4 as previously described [31]. Eyes were enucleated on day 18 and inflammation was assessed histopathologically by scoring on a scale of 0 to 4 in half-point increments, according to a semi-quantitative system [15].

\section{Oral administration of STA-5326}

In most experiments, $5 \mathrm{mg} / \mathrm{kg}$ or $20 \mathrm{mg} / \mathrm{kg}$ STA-5326 (Synta Pharmaceuticals Corporation, Lexington, MA) or vehicle only ( $0.5 \%$ carboxyl methyl cellulose) was orally administered once a day for six days a week from day 0 to day 14 after immunization. In the effector phase experiments, $20 \mathrm{mg} / \mathrm{kg} \mathrm{STA-5326}$ or vehicle was orally administered once a day, from day 9 to day 14 after immunization.

\section{In vitro proliferation and cytokine assay}

Cervical lymph node cells obtained from immunized mice on day 18 ( $2 \times 10^{5}$ cells/well) were cultured in $0.2 \mathrm{ml}$ RPMI 1640 (Sigma Aldrich, St. Louis, MO) containing 10 mM HEPES (Invitrogen Life Technologies, Carlsbad, CA), $0.1 \mathrm{mM}$ nonessential amino acid (Invitrogen Life Technologies, Carlsbad, CA), 1 $\mathrm{mM}$ sodium pyruvate (Invitrogen Life Technologies, Carlsbad, CA), $100 \mathrm{U} / \mathrm{ml}$ penicillin (Invitrogen Life Technologies, Carlsbad, CA), $100 \mu \mathrm{g} / \mathrm{ml}$ streptomycin (Invitrogen Life Technologies, Carlsbad, CA), $1 \times 10^{-5} \mathrm{M}$ 2-mercaptoethanol (2ME; Sigma Aldrich, St. Louis, MO), 10\% FCS, and $10 \mu \mathrm{g} / \mathrm{ml}$ $\mathrm{IRBP}_{1-20}$. For cytokine assay, supernatants were collected after 72 hours and analysed for IFN- $\gamma$, IL-4 and IL-1 7 by quantitative capture ELISA using quantikine ELISA kits (R\&D Systems, Minneapolis, MN) and mouse IL-17 ELISA Ready-SETGo kits (eBioscience, San Diego, CA). Cell proliferation was evaluated using a cell proliferation assay (bromodeoxyuridine; Roche Diagnostics, Mannheim, Germany).

\section{Intracellular cytokine flow cytometry}

Cervical lymph node cells obtained from immunized mice were seeded at $1.5 \times 10^{6}$ cells/well in 24 -well plates and stimulated with $10 \mu \mathrm{g} / \mathrm{ml} \mathrm{IRBP}_{1-20}$ for 72 hours. The stimulated cervical lymph node cells were harvested and cultured in vitro with 5 $\mathrm{ng} / \mathrm{ml} \mathrm{PMA}, 500 \mathrm{ng} / \mathrm{ml}$ ionomycin and cytokine secretion blocker Gogi-stop (Brefeldin A; BD Bioscience, San Jose, CA) for four hours, then stained using fluorescein isothiocyanateconjugated monoclonal antibodies against mouse CD4 or CD8 (BD Bioscience, San Jose, CA). The cells were washed, fixed, permeabilised with Cytofix/Cytoperm (BD Bioscience, San Jose, CA), intracellularly stained with phycoerythrin-conjugated antibodies against IFN- $\gamma$ and IL-17 (BD Bioscience, San Jose, CA) and analyzed on a flow cytometer (FACSCalibur; BD Bioscience, San Jose, CA) using acquisition and analysis software (CellQuest; Becton Dickinson, Franklin Lakes, NJ). 


\section{IL-12 production in the serum of STA-5326-treated or vehicle-treated mice after immunization}

Mice were immunized as described above, and $5 \mathrm{mg} / \mathrm{kg}$ or 20 $\mathrm{mg} / \mathrm{kg} \mathrm{STA-5326}$ or vehicle alone was orally administered once a day from day 0 to day 14 after immunization. STA5326-treated or vehicle-treated mice were euthanased on day 18 after immunization, and serum from individual mice were collected for IL-12 p40 measurement using quantikine ELISA kits (R\&D systems, Minneapolis, MN).

\section{Statistical analysis}

Results of experiments were analyzed using Mann-Whitney $U$ test and Student's $t$-test. Data are expressed as the mean \pm standard deviation (SD). Means were considered to be significantly different for $p<0.05$. All experiments were repeated at least twice, with similar results confirmed.

\section{Results}

\section{STA-5326 does not alter body weight in EAU mice}

To assess for possible toxicity of STA-5326, the body weight of mice was measured every day after immunization with IRBP peptide and CFA. Body weight did not change in either $5 \mathrm{mg} /$ $\mathrm{kg}$ or $20 \mathrm{mg} / \mathrm{kg}$ STA-5326-treated or vehicle-treated mice during administration (Figure 1a).

\section{The level of IL-12 p40 in serum is decreased in STA-5326- treated mice}

STA-5326 has been reported to inhibit the expression of genes encoding the $\mathrm{p} 40$ subunit present in both IL-12 and IL23 [29]. To determine if oral administration of STA-5326 changes the level of IL-12p40 in vivo, we examined the level

\section{Figure 1}

(a)

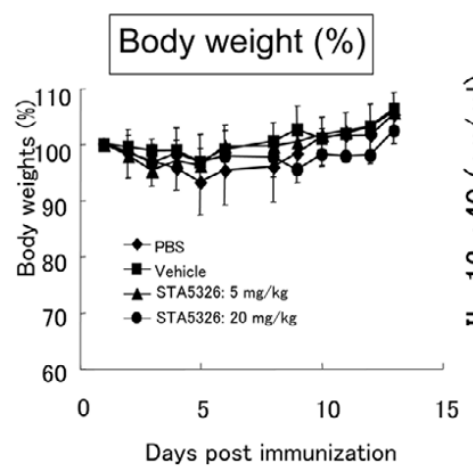

(b)

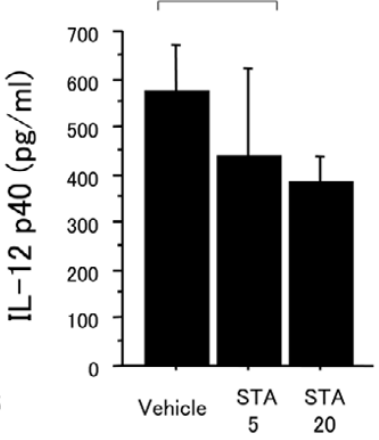

The level of IL-12 p40 in serum is reduced in STA-5326-treated mice. (a) STA-5326 at a dose of $5 \mathrm{mg} / \mathrm{kg}$ or $20 \mathrm{mg} / \mathrm{kg}$ or vehicle only was orally administered once a day six days a week from day 0 to day 14 after immunization with human interphotoreceptor retinoid binding protein (IRBP) peptide, and body weight was measured daily. (b) STA5326 at a dose of $5 \mathrm{mg} / \mathrm{kg}$ or $20 \mathrm{mg} / \mathrm{kg}$ or vehicle only was orally administered from day 0 to day 14 after immunization. Individual mice sera were collected on day 18 after immunization and the level of IL-12 p40 was assayed by ELISA. Statistical analysis was performed using Student's $t$-test. of IL-12 p40 in serum. STA-5326 at a dose of $5 \mathrm{mg} / \mathrm{kg}$ or 20 $\mathrm{mg} / \mathrm{kg}$ or vehicle only was orally administered from day 0 to day 14 after immunization. Serum from individual mice was collected on day 18 after immunization, and IL-12 p40 was assayed by ELISA. The level of IL-12 p40 was reduced in STA5326-treated mice, particularly in the high-dose group, compared with vehicle-treated mice (Figure 1b). These data indicate that oral administration of STA-5326 is capable of reducing the level of $\mathrm{IL}-12 \mathrm{p} 40$ in vivo.

\section{Oral administration of STA-5326 reduces the severity of EAU by clinical and pathological analysis}

We confirmed that STA-5326 treatment decreases the level of II-12 p40 in vivo, and we next tested if oral administration of STA-5326 is effective in EAU. C57BL/6 mice were immunized with $200 \mu \mathrm{g}$ human IRBP peptide 1-20 and treated with 5 $\mathrm{mg} / \mathrm{kg}$ or $20 \mathrm{mg} / \mathrm{kg}$ STA-5326 or vehicle only from day 0 to day 14 after immunization. The incidence and severity of EAU in STA-5326-treated or vehicle-treated mice were evaluated on days 14 and 18 after immunization. Fundus examination revealed that the severity of EAU was ameliorated in STA5326-treated mice compared with vehicle-treated mice (Figure 2a). Histopathological examination of eyes from vehicletreated mice showed severe inflammatory changes. Inflammatory cell infiltration into the vitreous cavity and throughout all layers of the retina, with intensive retinal vasculitis and partial destruction of the retinal architecture, was observed (Figure 2b). In contrast, STA-5326-treated mice exhibited some inflammatory cell infiltration into the vitreous cavity, but only a few infiltrating cells in the retina with retinal layers remaining intact (Figure 2b). This effect on reducing inflammation was dose-dependent, with substantial suppression observed with a dose of $5 \mathrm{mg} / \mathrm{kg}$ and stronger suppression observed with a dose of $20 \mathrm{mg} / \mathrm{kg}$ (Figure 2c). These results clearly indicate that oral administration of SAT-5326 is effective in suppressing inflammation in EAU.

\section{IL-17 production and the proportion of IL-17-producing cells of draining lymph nodes are significantly reduced in STA-5326-treated mice}

STA-5326 is a potent IL-12/IL-23 inhibitor, so we examined antigen-specific proliferation and cytokine production of IFN- $\gamma$, $\mathrm{IL}-17$ and IL-4. Immunized mice were treated with $5 \mathrm{mg} / \mathrm{kg}$ or $20 \mathrm{mg} / \mathrm{kg}$ STA-5326 or vehicle only from day 0 to day 14 , and draining lymph node cells were collected on day 18 after immunization and pooled within each group. The cells were stimulated with $10 \mu \mathrm{g} / \mathrm{ml}$ human IRBP peptide 1-20 for 72 hours and pulsed with bromodeoxyuridine for the last 24 hours. The proliferation of antigen-specific cells from STA5326-treated mice was reduced compared with that from vehicle-treated mice (Figure 3a). Next, draining lymph node cells collected on day 18 after immunization were stimulated with $10 \mu \mathrm{g} / \mathrm{ml}$ human IRBP peptide $1-20$ for 72 hours, and supernatants collected at 72 hours were assayed by ELISA. Lymph node cultures from STA-5326-treated mice showed 
Figure 2
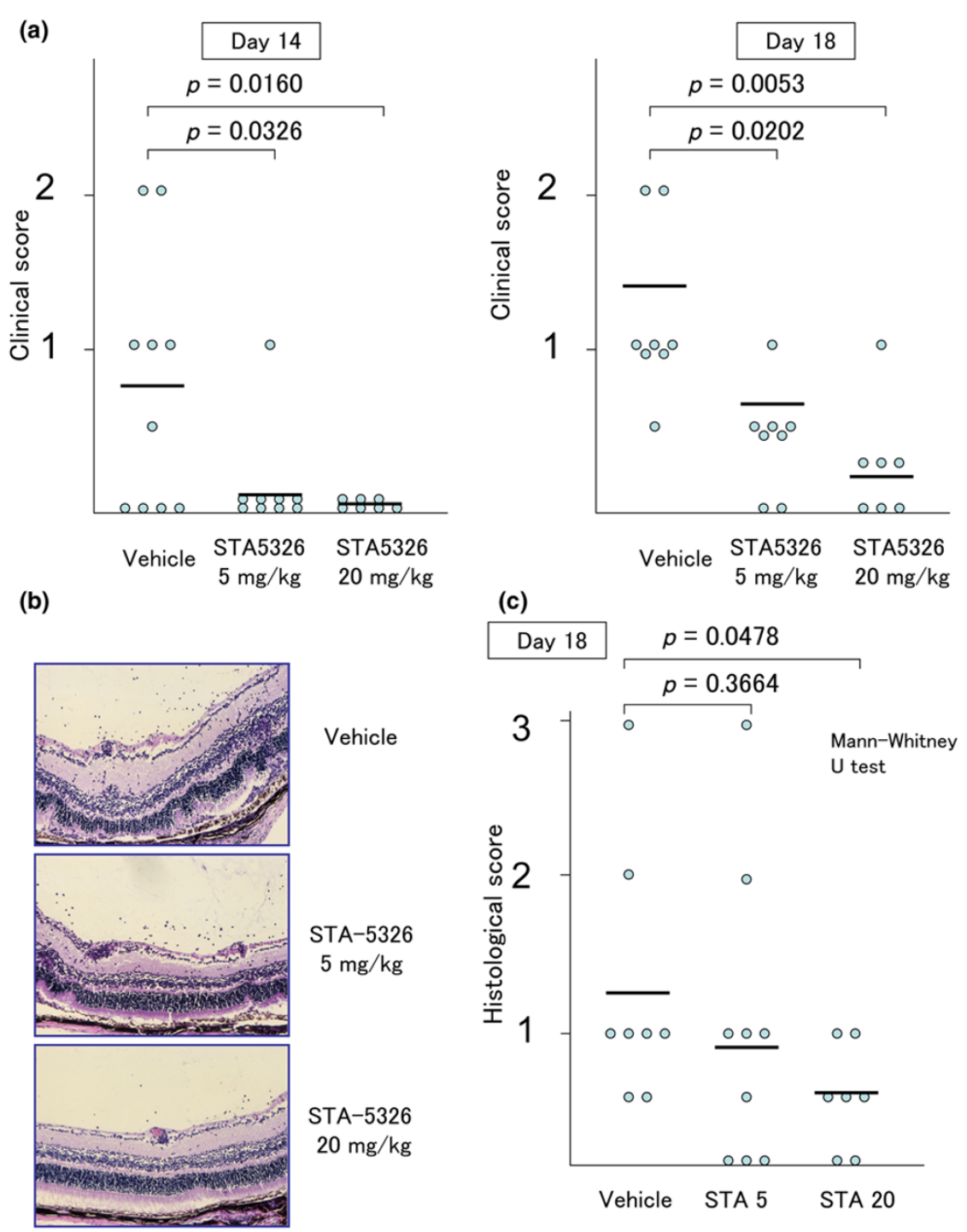

Oral administration of STA-5326 reduces the severity of experimental autoimmune uveoretinitis (EAU) by clinical and histopathological analysis. (a) Clinical score of EAU in STA-5326-treated or vehicle-treated mice. Immunized mice were treated with $5 \mathrm{mg} / \mathrm{kg}$ or $20 \mathrm{mg} / \mathrm{kg} \mathrm{STA-5326}$ or vehicle from day 0 to day 14 after immunization. EAU findings were evaluated on day 14 and day 18 after immunization. (b) Histopathological images of eyes from STA-5326-treated or vehicle-treated mice. Eyes enucleated on day 18 after immunization from STA-5326-treated or vehicletreated mice were examined. Magnification $\times 400$. (c) Histopathological score of EAU in STA-5326-treated or vehicle-treated mice. Each point on the graph represents the clinical or pathological score of one mouse. Each bar on the graph represents the average clinical or histopathological score for each group. Statistical analysis was performed by Mann-Whitney $\mathrm{U}$ test.

elevated production of IFN- $\gamma$ and decreased production of IL17 compared with those from vehicle-treated mice (Figures $3 b$ and $3 c$ ). IL-4 was not detected in either group (Figure 3d). The population of IFN- $\gamma$-producing or IL-17-producing draining lymph node cells from mice treated with $20 \mathrm{mg} / \mathrm{kg}$ STA-5326 or vehicle-treated mice was also examined. Cultured lymph node cells were stimulated with PMA/ionomycin, followed by intracellular staining for IFN- $\gamma$ and IL-17. Although the number of IFN- $\gamma$-producing CD4+ T cells (Th1 cells) was the same in mice treated with STA-5326 or vehicle only, the number of IL17-producing CD4+ $\mathrm{T}$ cells (Th17 cells) was reduced in STA- 5326-treated mice (Figures $3 e$ and 3f). The number of IFN- $\gamma$ producing and IL-17-producing CD8 $+\mathrm{T}$ cells was no different between the two groups (Figures $3 e$ and $3 f$ ). These data demonstrate that administration of STA-5326 during the entire phase of EAU reduces the expansion of Th17 cells, but not Th1 cells.

\section{Oral administration of STA-5326 during the effector phase reduces the severity of EAU by clinical analysis}

IL-23 is known to be required for the promotion of Th17 cells in vivo, [4] so we examined if STA-5326 was effective not only 

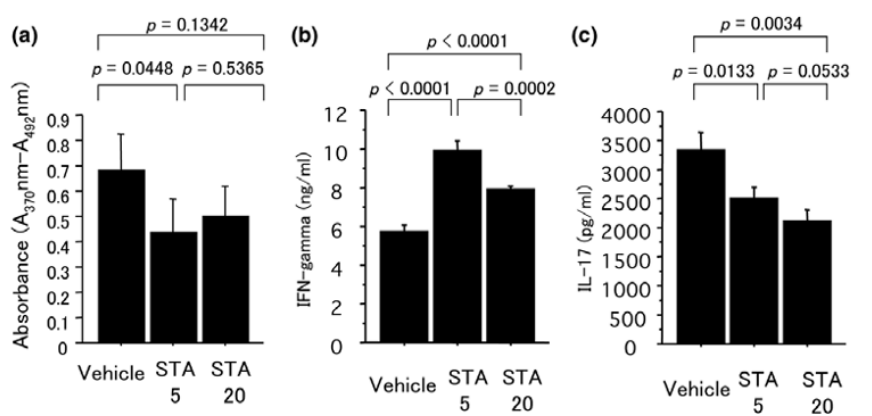

(e)
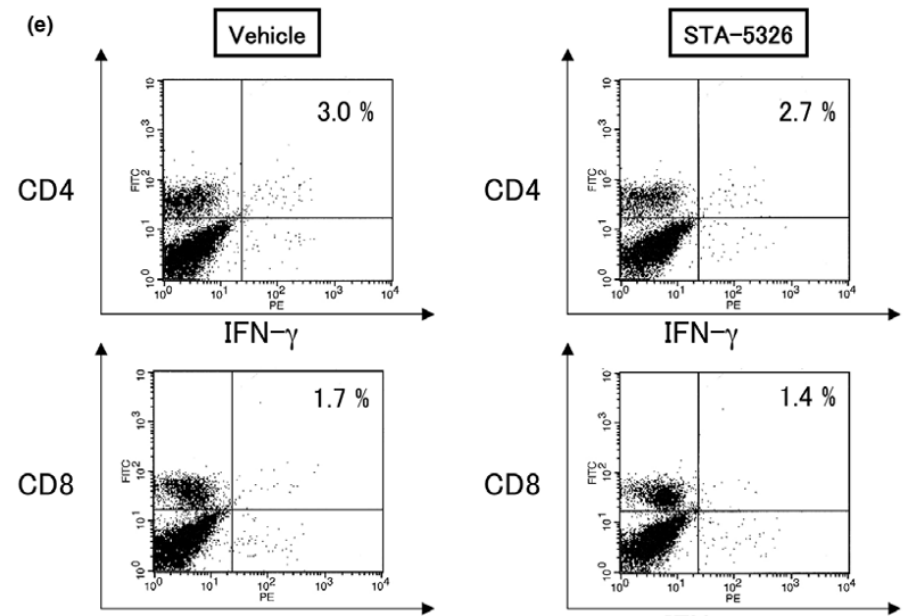

IFN- $\gamma$

(f)
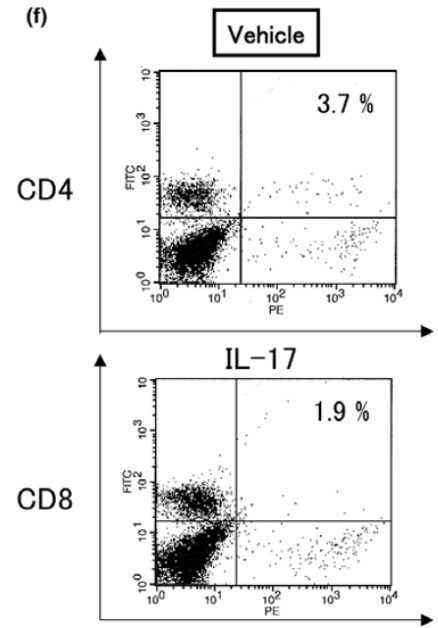

IL-17

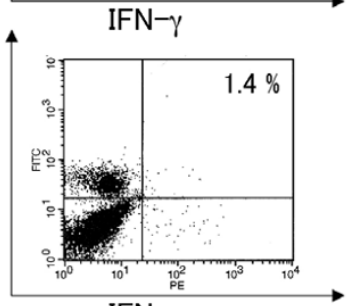

IFN- $\gamma$
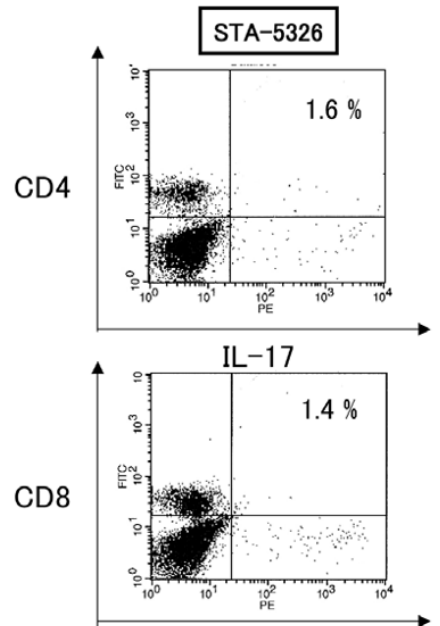

IL-17

Antigen specific proliferation is decreased in lymph node cells of STA-5326-treated mice, and IL-17 production and the proportion of Th17 cells from draining lymph nodes are significantly reduced in STA-5326-treated mice. (a) Antigen specific proliferation of draining lymph nodes in STA-5326-treated or vehicle-treated mice. Immunized mice were treated with $5 \mathrm{mg} / \mathrm{kg}$ or $20 \mathrm{mg} / \mathrm{kg} \mathrm{STA-5326}$ or vehicle from day 0 to day 14 after immunization. Draining lymph node cells collected on day 18 after immunization were pooled within each group. Cultures were stimulated with $10 \mu \mathrm{g} / \mathrm{ml}$ human experimental autoimmune uveoretinitis (IRBP) peptide 1-20 for 72 hours and pulsed with bromodeoxyuridine for the last 24 hours. (b-d) Cytokine production of interferon (IFN) $\gamma$, interleukin (IL) 17 and IL-4 by draining lymph node cells from STA-5326-treated or vehicle-treated mice. Immunized mice were treated with $5 \mathrm{mg} / \mathrm{kg}$ or $20 \mathrm{mg} / \mathrm{kg}$ STA-5326 or vehicle from day 0 to day 14 after immunization. Draining lymph node cells collected on day 18 after immunization were pooled within each group. Cultures were stimulated with $10 \mu \mathrm{g} / \mathrm{ml}$ IRBP ${ }_{1-20}$ for 72 hours, and supernatants collected at 72 hours were assayed by ELISA. (a-d) Statistical analysis was performed using Student; $t$-test. (e and f) Intracellular cytokine staining of draining lymph node cells in $20 \mathrm{mg} / \mathrm{kg}$ STA-5326 or vehicle-treated mice. Draining lymph node cells collected on day 18 were stimulated with IRBP ${ }_{1-20}$ for 72 hours, and the cultured cells were incubated with PMA plus ionomycin and brefeldin A and stained with CD4, CD8 and intracellular IFN- $\gamma$ and IL-17. The percentage shown in the upper right quadrant is for IFN- $\gamma$ or IL-17 positive cells in CD4+ ${ }^{+}$cells. 
when administered throughout the entire phase of EAU, but also after effector $\mathrm{T}$ cells had already been generated. Immunized mice were treated with $20 \mathrm{mg} / \mathrm{kg}$ STA-5326 or vehicle only from day 9 to day 14 after immunization (the effector phase). EAU severity was evaluated on day 15 and day 18 after immunization. Fundus examination revealed that STA5326 treatment significantly reduced the severity of EAU on day 15 (Figure 4). This suggests that oral administration of STA-5326, even during the effector phase, is only capable of decreasing inflammation in EAU.

\section{Discussion}

In the present study, we showed that oral administration of the potent IL-12/IL-23 inhibitor, STA-5326, reduces the severity of EAU by clinical and histopathological analysis. In STA5326-treated mice, the serum level of IL-12 p40 was decreased. Although antigen specific IFN- $\gamma$ production was not inhibited in draining lymph node cells from STA-5326treated mice, IL-17 production and the proportion of IL-17producing cells were significantly reduced. Furthermore, oral administration of STA-5326 significantly ameliorated the severity of EAU even after effector cells were presumably generated.

Production of the Th1 cytokine, IFN- $\gamma$, was not reduced in STA-5326-treated mice. This was not expected, because reduced IFN- $\gamma$ production had been observed in an animal model of IBD treated with STA-5326 [29]. It is possible that decreased IL-1 7 production may be affecting IFN- $\gamma$ production during the late phase of EAU. Luger and colleagues showed that an enhanced Th1 response was observed in lymph node cells of IL-17 knockout mice, suggesting that IL-17 may have an antagonistic effect on the development of Th1 effectors [24]. Yoshimura and colleagues also demonstrated that antiIFN- $\gamma$ and anti-IL-4 antibody treatment augmented Th1 7 differentiation in vivo [23]. Therefore, IL-17 and IFN- $\gamma$ may be acting in a reciprocal fashion during the late phase of EAU, resulting in an absence of down-regulation of IFN- $\gamma$ due to reduced IL17 production in STA-5326-treated mice.

Oral administration of STA-5326 during the effector phase only resulted in decreased EAU inflammation on clinical analysis. It has recently been shown that systemic neutralization of IL-23 does not reverse EAU during the effector phase in B10.RIII mice [24]. IL-23 is required for expansion and maintenance of Th17 effectors [4]. In addition, Tarrant and colleagues clearly demonstrated that endogenous IL-12 plays a role in pathogenesis during the expression phase of EAU, after uveitogenic effector cells have been primed [25]. Down-regulation of the IL-12/Th1 pathway and the IL-23/Th17 pathway may be necessary for significant amelioration of EAU during the effector phase and the induction phase, respectively. This would explain why STA-5326, by blocking both IL-12 and IL23 , is efficacious in both phases.

Although the present study examined clinical and histopathological changes only on day 14 and day 18 when STA-5326 was administered during the entire course of EAU, the possibility exists that STA-5326 may be merely delaying the onset of EAU rather than decreasing the overall severity of inflammation. However, STA-5326 also decreased inflammation when administered only during the effector phase of EAU, after the presumed production of uveitogenic effector cells and migra-

Figure 4
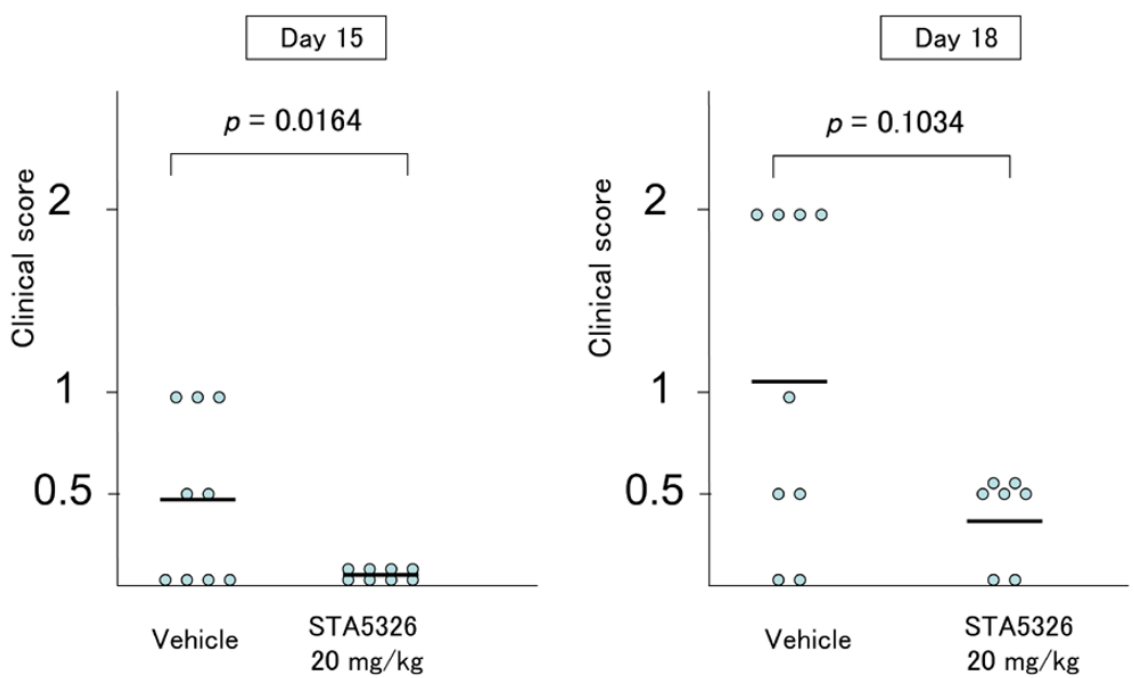

Oral administration of STA-5326 during the effector phase reduces the severity of experimental autoimmune uveoretinitis (EAU) by clinical analysis. Clinical score of EAU in STA-5326-treated or vehicle-treated mice. Immunized mice were treated with $20 \mathrm{mg} / \mathrm{kg}$ STA-5326 or vehicle from day 9 to day 14 after immunization. Clinical findings were evaluated on day 15 and day 18 after immunization. Statistical analysis was performed by Mann-Whitney U test. 
tion of these cells to the eye. This suggests that STA-5326 may have a therapeutic effect on ocular inflammation in the clinical setting.

Our data are in agreement with previous reports showing that IL-12 p40 knockout and IL-23 p19 knockout mice are highly resistant to EAU and anti-IL-12 antibody treatment prevents EAU induction [24-26]. The present study showed that serum levels of IL-12 p40 were reduced in STA-5326-treated mice in a dose-dependent manner. IL-12 and IFN- $\gamma$ are known to be important cytokines for host defense and immune surveillance. Recently, the IL-23/IL-17 pathway has been shown to be necessary for host defence against Klebsiella pneumoniae $[32,33]$. p40 is a subunit of both IL-12 and IL-23, and decreased levels of IL-12 p40 may affect a broad range of immune responses. The present study showed that production of IFN- $\gamma$ from draining lymph node cells was not decreased in mice treated with STA-5326 through the entire course of EAU. Therefore, the safety of STA- 5326 administration would need to be assessed further in terms of effect on host defence mechanisms.

It has been demonstrated that STA-5326 inhibits the expression of genes encoding the 440 subunit present in both IL-12 and IL-23 by way of selective inhibition of c-Rel translocation [29]. However, in the present study, it is not clear where SAT5326 is having this effect. STA-5326 has been reported to inhibit IL-12 production by human monocytes, monocytederived dendritic cells, and the human monocyte cell line THP1 [29]. Serum levels of IL-12/IL-23 p40 were significantly decreased in STA-5326-treated mice in the current study, so STA-5326 may be blocking activation of the promoter for IL$12 / \mathrm{IL}-23 \mathrm{p} 40$ in macrophages and dendritic cells in lymph nodes, spleen and blood. It is also likely that STA- 5326 blocks c-Rel translocation in ocular tissues and infiltrating inflammatory cells, including ocular antigen presenting cells, resulting in inhibition of gene expression of IL-12/LL-23 in the uveitic lesion.

It has been reported that STA-5326 does not affect the production of inflammatory cytokines, including IL-1 $\beta, \mathrm{IL}-2$, IL-4, IL-6, IL-8 and IL-18, in an IFN- $\gamma$ stimulated human monocytic cell line and in mouse spleen cells [29]. Although the NF-KB family p50/p65 is the most common form of NF-KB to activate the promoters of many genes, including those for TNF- $\alpha$ and IL-6, the c-Rel-containing form is essential for activation of the p40 gene in macrophages [27]. Furthermore, it has recently been shown that c-Rel binds to the $\mathrm{\kappa B}$ sites on this promoter and controls p19 gene expression in dendritic cells [28]. Thus, c-Rel appears to be a specific transcriptional regulator for both IL-12 and IL-23. The present study also showed that serum levels of IL-12 p40 were decreased in STA-5326-treated mice. Taken together, we believe that STA-5326 represents a potent IL-12/IL-23 inhibitor.
Compared with anti-cytokine antibodies that act by neutralization of IL-12 and IL-23 proteins that have already been produced, STA-5326 acts by selectively shutting off transcription of the p35, p40 and p19 genes [29] and has the added advantage of being a small-molecule that can be administered orally. Therefore, we believe that STA- 5326 has great potential as a therapeutic agent. Accordingly, a biomarker study in which patients with stable psoriasis vulgaris skin plaques received oral STA-5326, showed that expression of IL-23 p19 and IL$12 /$ IL-23 p40 was reduced [34], and STA-5326 is currently undergoing evaluation in a phase 2a study in rheumatoid arthritis, a disease characterized by elevated IL-12 levels.

\section{Conclusions}

Oral administration of STA-5326 was effective in suppressing inflammation in the EAU model, and reduced the serum level of IL-12/IL-23 p40 and the expansion of IL-17-producing cells. STA-5326 represents a new promising therapeutic modality for refractory uveitis in humans.

\section{Competing interests}

YW is an employee of Synta Pharmaceuticals Corporation. There were no competing interests for the remaining authors.

\section{Authors' contributions}

HK contributed to the design of the study, performance of in vivo experiments, data analysis and manuscript preparation. MN contributed to performance of in vivo experiments. YS and TW performed the in vitro experiments. YW provided vital reagents and contributed to data analysis and manuscript preparation. AAO contributed to data analysis and manuscript preparation. All authors read and approved the final manuscript.

\section{Acknowledgements}

This work was supported by Grant-in-Aid 17791258 for Scientific Research from the Japan Society for the Promotion of Science. We thank Nobuko Takahashi for her technical assistance.

STA-5326 was provided by Synta Pharmaceuticals Corporation. (Lexington, MA).

\section{References}

1. Oppmann B, Lesley R, Blom B, Timans JC, Xu Y, Hunte B, Vega F, Yu N, Wang J, Singh K, Zonin F, Vaisberg E, Churakova T, Liu M, Gorman D, Wagner J, Zurawski S, Liu Y, Abrams JS, Moore KW, Rennick D, de Waal-Malefyt R, Hannum C, Bazan JF, Kastelein RA: Novel p19 protein engages IL-12p40 to form a cytokine, IL-23, with biological activities similar as well as distinct from IL-12. Immunity 2000, 13:715-725.

2. Parham C, Chirica M, Timans J, Vaisberg E, Travis M, Cheung J, Pflanz S, Zhang R, Singh KP, Vega F, To W, Wagner J, O'Farrell AM, McClanahan T, Zurawski S, Hannum C, Gorman D, Rennick DM, Kastelein RA, de Waal Malefyt R, Moore KW: A receptor for the heterodimeric cytokine IL-23 is composed of IL-12Rbeta1 and a novel cytokine receptor subunit, IL-23R. J Immuno/ 2002, 168:5699-5708.

3. Aggarwal S, Ghilardi N, Xie MH, de Sauvage FJ, Gurney AL: Interleukin-23 promotes a distinct CD4 T cell activation state characterized by the production of interleukin-17. J Biol Chem 2003, 278:1910-1914. 
4. Langrish $\mathrm{CL}$, Chen $\mathrm{Y}$, Blumenschein WM, Mattson J, Basham B, Sedgwick JD, McClanahan T, Kastelein RA, Cua DJ: IL-23 drives a pathogenic $T$ cell population that induces autoimmune inflammation. J Exp Med 2005, 201:233-240.

5. Leonard JP, Waldburger KE, Goldman SJ: Prevention of experimental autoimmune encephalomyelitis by antibodies against interleukin 12. J Exp Med 1995, 181:381-386.

6. Malfait AM, Butler DM, Presky DH, Maini RN, Brennan FM, Feldmann M: Blockade of IL-12 during the induction of collageninduced arthritis (CIA) markedly attenuates the severity of the arthritis. Clin Exp Immunol 1998, 111:377-383.

7. Cua DJ, Sherlock J, Chen Y, Murphy CA, Joyce B, Seymour B, Lucian L, To W, Kwan S, Churakova T, Zurawski S, Wiekowski M, Lira SA, Gorman D, Kastelein RA, Sedgwick JD: Interleukin-23 rather than interleukin-12 is the critical cytokine for autoimmune inflammation of the brain. Nature 2003, 421:744-748.

8. Murphy CA, Langrish CL, Chen Y, Blumenschein W, McClanahan T, Kastelein RA, Sedgwick JD, Cua DJ: Divergent pro- and antiinflammatory roles for IL-23 and IL-12 in joint autoimmune inflammation. J Exp Med 2003, 198:1951-1957.

9. Yen $D$, Cheung J Scheerens $H$, Poulet $F$, McClanahan $T$, McKenzie B, Kleinschek MA, Owyang A, Mattson J, Blumenschein W, Murphy E, Sathe M, Cua DJ, Kastelein RA, Rennick D: IL-23 is essential for $\mathrm{T}$ cell-mediated colitis and promotes inflammation via IL-17 and IL-6. J Clin Invest 2006, 116:1310-1316.

10. Mannon PJ, Fuss IJ, Mayer L, Elson CO, Sandborn WJ, Present D, Dolin B, Goodman N, Groden C, Hornung RL, Quezado M, Yang Z, Neurath MF, Salfeld J, Veldman GM, Schwertschlag U, Strober W: Anti-interleukin-12 antibody for active Crohn's disease. $N$ Engl J Med 2004, 351:2069-2079.

11. Toichi E, Torres G, McCormick TS, Chang T, Mascelli MA, Kauffman CL, Aria N, Gottlieb AB, Everitt DE, Frederick B, Pendley CE, Cooper KD: An anti-IL-12p40 antibody down-regulates type 1 cytokines, chemokines, and IL-12/IL-23 in psoriasis. J Immunol 2006, 177:4917-4926.

12. Krueger GG, Langley RG, Leonardi C, Yeilding N, Guzzo C, Wang $Y$, Dooley LT, Lebwohl M: A human interleukin-12/23 monoclonal antibody for the treatment of psoriasis. $N$ Engl J Med 2007, 356:580-592.

13. Wacker WB, Lipton MM: Experimental allergic uveitis: homologous retina as uveitogenic antigen. Nature 1965, 206:253-254.

14. Caspi RR, Roberge FG, Chan CC, Wiggert B, Chader GJ, Rozenszajn LA, Lando Z, Nussenblatt RB: A new model of autoimmune disease. Experimental autoimmune uveoretinitis induced in mice with two different retinal antigens. J Immunol 1988, 140:1490-1495.

15. Chan CC, Caspi RR, Ni M, Leake WC, Wiggert B, Chader GJ, Nussenblatt RB: Pathology of experimental autoimmune uveoretinitis in mice. J Autoimmun 1990, 3:247-255.

16. Caspi RR, Roberge FG, McAllister CG, el-Saied M, Kuwabara T, Gery I, Hanna E, Nussenblatt RB: T cell lines mediating experimental autoimmune uveoretinitis (EAU) in the rat. $J$ Immunol 1986, 136:928-933

17. Gregerson DS, Obritsch WF, Fling SP, Cameron JD: S-antigenspecific rat $T$ cell lines recognize peptide fragments of $S$-antigen and mediate experimental autoimmune uveoretinitis and pinealitis. J Immunol 1986, 136:2875-2882.

18. Mochizuki M, Kuwabara T, McAllister C, Nussenblatt RB, Gery I: Adoptive transfer of experimental autoimmune uveoretinitis in rats. Immunopathogenic mechanisms and histologic features. Invest Ophthalmol Vis Sci 1985, 26:1-9.

19. Caspi RR: Th1 and Th2 responses in pathogenesis and regulation of experimental autoimmune uveoretinitis. Int Rev Immunol 2002, 21:197-208.

20. Tang J, Zhu W, Silver PB, Su SB, Chan CC, Caspi RR: Autoimmune uveitis elicited with antigen-pulsed dendritic cells has a distinct clinical signature and is driven by unique effector mechanisms: initial encounter with autoantigen defines disease phenotype. J Immunol 2007, 178:5578-5587.

21. Amadi-Obi A, Yu CR, Liu X, Mahdi RM, Clarke GL, Nussenblatt RB, Gery I, Lee YS, Egwuagu CE: TH17 cells contribute to uveitis and scleritis and are expanded by IL-2 and inhibited by IL27/STAT1. Nat Med 2007, 13:711-718.

22. Peng $Y$, Han G, Shao H, Wang Y, Kaplan HJ, Sun D: Characterization of IL-17+ interphotoreceptor retinoid-binding proteinspecific $\mathrm{T}$ cells in experimental autoimmune uveitis. Invest Ophthalmol Vis Sci 2007, 48:4153-4161.
23. Yoshimura $T$, Sonoda $\mathrm{KH}$, Miyazaki $\mathrm{Y}$, Iwakura $\mathrm{Y}$, Ishibashi $\mathrm{T}$, Yoshimura A, Yoshida H: Differential roles for IFN-gamma and IL-17 in experimental autoimmune uveoretinitis. Int Immunol 2008, 20:209-214.

24. Luger D, Silver PB, Tang J, Cua D, Chen Z, Iwakura Y, Bowman EP, Sgambellone NM, Chan CC, Caspi RR: Either a Th17 or a Th1 effector response can drive autoimmunity: conditions of disease induction affect dominant effector category. J Exp Med 2008, 205:799-810.

25. Tarrant TK, Silver PB, Chan CC, Wiggert B, Caspi RR: Endogenous IL-12 is required for induction and expression of experimental autoimmune uveitis. $J$ Immunol 1998, 161:122-127.

26. Yokoi H, Kato K, Kezuka T, Sakai J, Usui M, Yagita H, Okumura K: Prevention of experimental autoimmune uveoretinitis by monoclonal antibody to interleukin-12. Eur J Immunol 1997, 27:641-646.

27. Sanjabi S, Hoffmann A, Liou HC, Baltimore D, Smale ST: Selective requirement for c-Rel during IL-12 P40 gene induction in macrophages. Proc Natl Acad Sci USA 2000, 97:12705-12710.

28. Carmody RJ, Ruan Q, Liou HC, Chen YH: Essential roles of c-Rel in TLR-induced IL-23 p19 gene expression in dendritic cells. $J$ Immunol 2007, 178:186-191.

29. Wada Y, Lu R, Zhou D, Chu J, Przewloka T, Zhang S, Li L, Wu Y, Qin J, Balasubramanyam V, Barsoum J, Ono M: Selective abrogation of Th1 response by STA- a potent IL-12/IL-23 inhibitor. Blood 2007, 109:1156-1164.

30. Avichezer D, Chan CC, Silver PB, Wiggert B, Caspi RR: Residues 1-20 of IRBP and whole IRBP elicit different uveitogenic and immunological responses in interferon gamma deficient mice. Exp Eye Res 2000, 71:111-118.

31. Thurau SR, Chan CC, Nussenblatt RB, Caspi RR: Oral tolerance in a murine model of relapsing experimental autoimmune uveoretinitis (EAU): induction of protective tolerance in primed animals. Clin Exp Immunol 1997, 109:370-376.

32. Happel Kl, Zheng M, Young E, Quinton LJ, Lockhart E, Ramsay AJ, Shellito JE, Schurr JR, Bagby GJ, Nelson S, Kolls JK: Cutting edge: roles of Toll-like receptor 4 and IL-23 in IL-17 expression in response to Klebsiella pneumoniae infection. J Immunol 2003, 170:4432-4436.

33. Happel KI, Dubin PJ, Zheng M, Ghilardi N, Lockhart C, Quinton LJ Odden AR, Shellito JE, Bagby GJ, Nelson S, Kolls JK: Divergent roles of IL-23 and IL-12 in host defense against Klebsiella pneumoniae. J Exp Med 2005, 202:761-769.

34. Wada Y: IL-12/IL-23 inhibitors: a promising approach to the treatment of inflammatory disorders. Drugs of the Future 2008, 33:49-63. 